\title{
МОНІТОРИНГ РІЗНИХ ФОРМ МАСТИТУ У ГОСПОДАРСТВАХ СУМСЬКОї ОБЛАСТІ
}

Титух Ярослав Вікторович аспірант

Сумський національний аграрний університет (м. Суми, Україна) ORCID: 0000-0002-2504-0928

yaroslavusvet@gmail.com

В статті викладені результати моніторингу маститу корів у Сумській області. Мастит, спричинений інфекційними збудниками, досі вважається згубним для молочних тварин, впливає на їх добробут, а також несе величезні економічні збитки молочній галузі через зниження продуктивності та збільшення вибракування.

Дослідження проводили на молочних фрермах Сумської області. Процедури поводження з тваринами в рамках дослідження були затверджені Комітетом з етики Сумського національного аграрного університету. Тварин утримують у вільних стійлах. Доїння відбувається тричі на день. Досліди проводили на коровах у 1-5 лактації, що належали до стада голитинської породи великої рогатої худоби.

В результаті проведення досліджень було встановлено, що субклінічні форми маститу у молочних господарства виявляються набагато частіше, ніж клінічні. Захворювання корів на субклінічний мастит контролювали за кількістю соматичних клітин (КСК) у молощі. Найчастіше корови уражуються на субклінічний мастит (СМ) у перші місяці після отелення через виникнення фрізіологічного стресу у тварини. Захворювання поступово зменшуються під кінець періоду лактації і знову виникає рецидив в період запуску. Однак у здорових корів кількість соматичних клітин в молоці може коливатись протягом всього періоду лактації в межах фрізіологічної норми. У хворих тварин КСК різко збільшується і може переходити мастит з субклінічної форми у клінічну через ненадання своєчасного лікування.

При проведенні моніторингу маститу різної форми у корів в господарствах Сумської області встановлено, що субклінічна форма маститу діагностувалась частіше ніж клінічна у Сумському районі на 33,4 \%; у Лебединському - на 17,8 \%; у Конотопському - на 45,4 \%; у Шосткінському - на 42,8 \%; у Роменському - на 34,3 \%; у Охтирському - на 21,9 \%. Встановлено, що пік розвитку субклінічного маститу приходиться на 7-10 добу запалення і повертається до початкових значень за два тижні. За результатами визначення основного складу мікрофрлори у молоці корів встановлено, що основними збудниками субклінічного маститу є S. agalactiae (20\%), S aureus (17\%), S. epidermidis (15\%), E. fecalis (12\%), E. coli (10\%), Mycoplasma spp. (8 \%), гриби Candida (7 \%) та асоиійована мікрофлора (11\%).

Ключові слова: корови, субклінічний мастит, клінічний мастит, збудники субклінічного маститу, лактація.

DOI: https://doi.org/10.32845/bsnau.vet.2021.1.7

Вступ. Мастит, спричинений інфекційними збудниками, досі вважається згубним для молочних тварин, впливає на їх добробут, а також несе економічно величезні збитки молочній галузі через зниження продуктивності та збільшення відбракування. Мастит великої рогатої худоби - це запалення молочних залоз (вимені) великої рогатої худоби в більшості випадків спричинене бактеріальними збудниками,. Звичайна діагностика ірунтується на розпізнаванні клінічної та субклінічної формах захворювання. Це підкреслює важливість ранньої та швидкої ідентифікації / виявлення етіологічних агентів на рівні ферми, для якої розроблено декілька діагностичних методик. Існує багато причин, які сприяють виникненню та поширенню маститу у господарствах серед молочного стада. Не належний санітарний стан приміщень та нехтування проведенням санації вим'я перед доїнням може поширювати збудників маститу у стаді. Дезінфекція доїльних апаратів та обладнання також має важливе значення. Своєчасна діагностика та терапія субклінічного маститу у тварин в господарствах зменшує ризик поширення цього захворювання.

Аналіз останніх досліджень та публікацій. Мастит - це хвороба, яка має великий вплив на добробут тварин. Також це негативно позначається на прибутках фермерів і призводить до великих втрат виробництва в молочному секторі в усьому світі (Bardhan, 2013; Sinha et al., 2014).

Мастит великої рогатої худоби - це запалення молочних залоз (інтрамаммарне запалення) у корів. Захворювання спричинений в основному бактеріальними інфекціями, і на підставі епідеміології підрозділяється на два типи: контагіозний мастит і мастит, викликаний бактеріями з навколишнього середовища (Das et al., 2018). Перший викликається заразними

бактеріями, в тому числі S. aureus, Streptococcus agalactiae (S. agalactiae) і Mycoplasma spp. які передаються від інфікованої корови здоровій корові зазвичай під час доїння через руки, рушники або доїльний апарат, який діє як резервуар для бактерій. I навпаки, екологічний мастит викликається бактеріями, які поширюються в основному за межами доїльного залу, тобто бактерії-збудники потрапляють з навколишнього середовища. Для них природнім субстратом розмноження $€$ підстилка, грунт, гній, фекалії і вода (Halasa et al., 2007).

Мастит великої рогатої худоби призводить до збільшення витрат на отримання молока в тому, що стосується виробництва молока. Більш того, це також негативно впливає на склад молока, а також на його цінність (Kalinska et al., 2017). Мастит в значній мірі залежить від методів лікування; i, таким чином, вимагає більш досконалих технічних і біологічних методів, а також відповідних заохочень і стимулів. Фермери та ветеринарні лікарі повинні працювати відповідно до офіційних інструкцій по використанню обов'язкових протимікробних засобів (Klaas and Zadoks 2018). Протягом останнього століття були досягнуті значні успіхи в боротьбі з маститом; але через мінливу динаміку популяції, структури стада і більш суворих стандартів переробників, мастит стає складною хворобою і залишається головною проблемою молочної промисловості. Таким чином, необхідні подальші дослідження в цій області (Ruegg, 2017).

Мастит у великої рогатої худоби є важливою економічною проблемою в усьому світі, включаючи Канаду (Aghamohammadi et al., 2018), Німеччину (Hamann, 2001), Сполучене Королівство (Bennett et al., 1999), Нідерланди (Hogeveen et al., 2011) і Сполучені Штати Америки (Hadrich et 
al., 2018). Мастит великої рогатої худоби пов'язаний зі щоденною втратою від 1,0 до 2,5 кг молока протягом перших двох тижнів після початку і загальної втратою від 110 до 552 кг протягом всієї лактації в залежності від кількості і часу виникнення. Мастит також має тривалий вплив на надої, оскільки корови не відновлюють свій піковий удій в решту лактації. Незважаючи на різні передові методи управління розведенням великої рогатої худоби в молочному секторі, мастит і зараз залишається серйозною хворобою і однією з основних економічних проблем фермерів і власників молочних господарств. Крім того, споживання молока, ураженого маститом, може бути шкідливим для людини, оскільки патогени, стійкі до протимікробних препаратів, можуть передаватися через заражене непастеризоване молоко; отже, це також серйозна небезпека для громадської охорони здоров'я (Oliver and Murinda, 2012). Крім того, ризики для здоров'я, пов'язані з підвищеною стійкістю мікробів і залишками антибіотиків в молоці, призвели до збільшення споживчого попиту на органічні продукти, оскільки вони вироблені з допомогою традиційних сільськогосподарських систем, більш здорові і безпечні для споживання (Ruegg, 2009). Через зоонозної загрози молоко при маститі не можна вживати і продавати, що призводить до великих економічних втрат (Sharun et al., 2021). Заражене вим'я знижує вартість тварин на ринку і лягає економічним тягарем на власника через витрати на лікування.
Метою роботи було провести моніторинг поширеності маститу у молочних господарствах Сумської області.

Матеріал і методи досліджень. Дослідження проводили на молочних фермах сумської області. Процедури поводження з тваринами в рамках дослідження були затверджені Комітетом з етики Сумського національного аграрного університету (затвердження №: 2017/01). Тварин утримують у вільних стійлах. Доїння відбувається тричі на день. Досліди проводили на коровах у 1-5 лактації, що належали до стада голштинської породи великої рогатої худоби.

Експериментальних тварин розподіляли в окремі коробки після підтвердження тесту на субклінічний мастит. 3разки молока для дослідження збирали під час ранкового доїння з кожної чверті вимені у кількості 50 мл щотижня, починаючи з 7-го дня після отелення. Все дослідження проводилось відповідно до відповідних рекомендацій та норм.

Каліфорнійський тест на мастит використовували для вивчення тварин на субклінічний мастит (Bhulto et al., 2012) та мікроскопічний тест для підрахунку соматичних клітин (Prescott and Breed, 2010). Також у молоці мікробіологічними методами визначали мікроорганізми-збудники субклінічного маститу.

Результати та обговорення. У роботі був проведений діагностичний моніторинг поширеності маститу у молочних господарствах Сумської області.

Таблиия 1

Поширеність захворювань корів на мастит у господарствах Сумської області за період 2017-2020 роки

\begin{tabular}{|l|c|c|}
\multicolumn{1}{|c|}{ Господарства } & \multicolumn{2}{|c|}{ Кількість хворих тварин на мастит(\%) } \\
\cline { 2 - 3 } & \multicolumn{2}{|c|}{ Клінічна форма } \\
\hline Сумський район & 23,5 & 56,9 \\
\hline Лебединський район & 18,7 & 36,5 \\
\hline Конотопський район & 36,3 & 81,7 \\
\hline Шосткінський район & 25,4 & 68,2 \\
\hline Роменський район & 22,3 & 56,6 \\
\hline Охтирський район & 21,5 & 43,4 \\
\hline
\end{tabular}

В результаті проведених досліджень з'ясовано, що субклінічні форми маститу у молочних господарства виявляються набагато частіше, ніж клінічні. Так на молочно-товарних фермах субклінічна форма маститу діагностувалась частіше у Сумському районі на $33,4 \%$; у Лебединському - на $17,8 \%$; у Конотопському - на 45,4\%; у Шосткінському - на 42,8 \%; у Роменському - на 34,3\%; у Охтирському - на 21,9 $\%$. Отримані результати обумовлені санітарними умовами утримання корів, технологією доїння та періодом лактації.

Захворювання корів на субклінічний мастит контролю- вали за кількістю соматичних клітин (КСК) у молоці. Найчастіше корови уражуються на субклінічний мастит (СМ) у перші місяці після отелу через виникнення фізіологічного стресу у тварини. Захворювання поступово зменшуються пі кінець періоду лактації і знову виникає рецидив в період запуску. Однак у здорових корів кількість соматичних клітин в молоці може коливатись протягом всього періоду лактації в межах фрізіологічної норми. У хворих тварин КСК різко збільшується і може переходити мастит з субклінічної форми у клінічну через не надання своєчасного лікування.

Таблиця 2

Кількість соматичних клітин у молоці корів за субклінічного маститу $(M \pm m, n=10)$

\begin{tabular}{|c|c|c|c|c|c|}
\hline \multirow{2}{*}{ Лактація } & \multicolumn{5}{|c|}{ Кількість соматичних клітин в молоці, тис/см3 } \\
\cline { 2 - 5 } & Контроль (здорові & \multicolumn{4}{|c|}{ Період захворювання тварин (доба) } \\
\cline { 2 - 5 } & тварини) & Початок & 7 & 10 & 15 \\
\hline \multirow{2}{*}{1} & 75,3 & $8234,3^{*}$ & $15432,7^{*}$ & $20012,4^{*}$ & $9634,4^{*}$ \\
& $\pm 4,3$ & $\pm 123,5$ & $\pm 116,5$ & $\pm 275,0$ & $\pm 132,2$ \\
\hline \multirow{2}{*}{2} & 80,5 & $9672,8^{*}$ & $17236,6^{*}$ & $23412,4^{*}$ & $10453,6^{*}$ \\
& $\pm 4,2$ & $\pm 129,2$ & $\pm 118,8$ & $\pm 156,2$ & $\pm 120,3$ \\
\hline \multirow{2}{*}{3} & 78,5 & $10032,3^{*}$ & $14784,3^{*}$ & $25345,2^{*}$ & $11234,5^{*}$ \\
& $\pm 3,5$ & $\pm 145,0$ & $\pm 123,5$ & $\pm 135,5$ & $\pm 164,3$ \\
\hline \multirow{2}{*}{4} & 79,5 & $9340,5^{*}$ & $14355,2^{*}$ & $21138,2^{*}$ & $9543,9^{*}$ \\
& $\pm 4,5$ & $\pm 136,2$ & $\pm 128,7$ & $\pm 175,6$ & $\pm 112,5$ \\
\hline \multirow{2}{*}{5} & 82,6 & $10006,5^{*}$ & $16322,8^{*}$ & $23546,8^{*}$ & $11456,4^{*}$ \\
& $\pm 4,5$ & $\pm 153,6$ & $\pm 145,3$ & $\pm 175,1$ & $\pm 128,7$ \\
\hline
\end{tabular}

За результатами проведених досліджень встановлено, що в першу лактацію у корів спостерігали збільшення

КСК на сьому добу захворювання на 87,4 \%; на десяту - на 
143,0\%; на п'ятнадцяту - на 17,0 \%, порівняно до початку хвороби. У корів другої лактації також прослідковується тенденція збільшення запалення вим'я на сьому добу на 78,2 \%; на десяту - на $142 \%$; на п'ятнадцяту - на 8,0 \%. Крім того, можна зазначити, що найбільший рецидив захворювання на субклінічний мастит приходиться з сьомої по десяту добу. На п'ятнадцяту добу захворювання запалення дещо зменшується, на що вказує рівень соматичних клітин в молоці корів. Так у корів третьої лактації на сьому добу спостерігали збільшення КСК на 47.3\%; на десяту - на 152,6 \%; на п'ятнадцяту - на $11,9 \%$.

Дослідження кількості соматичних клітин в молоці корів дає можливість визначати фізіологічний стан вим'я та початок розвитку запальних процесів. Однак показник КСК необхідно визначати у кожній чверті молочної залози окремо, тому що запалення може виникати в кожній долі окремо. На початку розвитку субклінічного маститу локалізація запального процесу в ураженій долі вимені дає можливість запобігти розвитку хвороби в здорових чвертях молочної залози.

У корів четвертої лактації хворих на СМ кількість соматичних клітин в молоці збільшується на сьому добу захворювання на 53,6 \%; на десяту - на 126,3 \%; на п'ятнадцяту на 2,2 \%. За виробничими даними корови можуть хворіти на субклінічний мастит тривалий час і без ефективного лікування може переходити у хронічну форму запалення, що в свою чергу може призвести до виникнення гіпо- та агалактії у тварин.

У тварин п'ятої лактації відбувається підвищення показника КСК у ураженій долі вимені на сьому добу на 63,12 \%; на десяту - на 135,3 \%; на п'ятнадцяту - на 14,4 \%.

Також важливим показником у молоці є кількісний та видовий склад мікроорганізмів, що сприяють розвитку запальних процесів у вимені корів. У господарствах Сумської області при відборі проб молока також були виділені та ідентифріковані мікроорганізми, які і є основними збудниками субклінічного маститу корів.

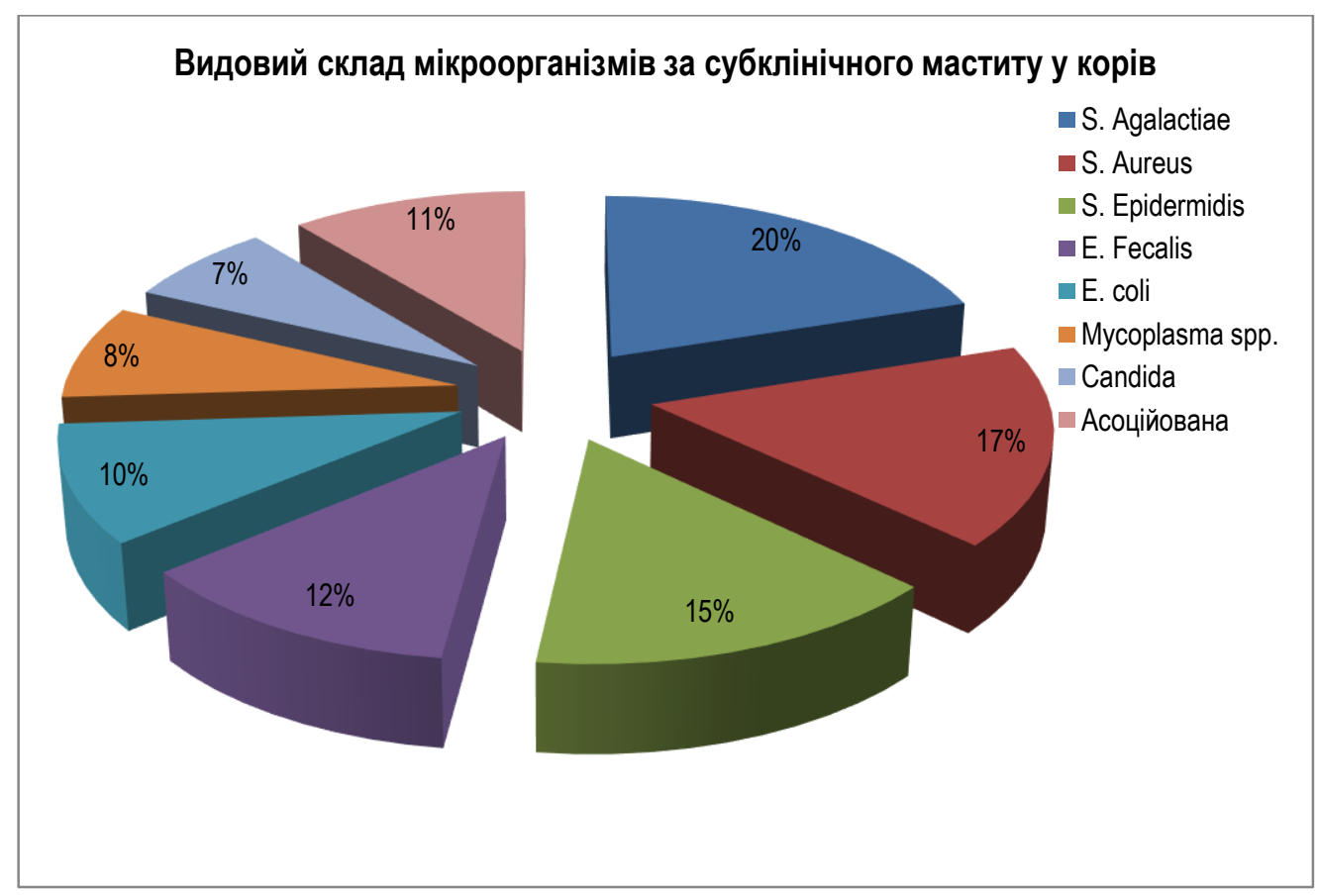

Рис.1. Видовий склад мікроорганізмів за субклінічного маститу у корів

За результатами визначення основного складу мікрофрлори у молоці корів встановлено, що основними збудниками субклінічного маститу $\in$ S. agalactiae (20\%), $S$ aureus (17\%), S. epidermidis (15\%), E. fecalis (12\%), E. coli (10\%), Mycoplasma spp. (8 \%), гриби Candida (7\%) та асоційована мікрофрлора (11\%).

Обговорення. В результаті проведених досліджень з'ясовано, що субклінічні форми маститу у молочних господарства виявляються набагато частіше, ніж клінічні. Так на молочнотоварних фермах субклінічна форма маститу діагностувалась частіше, ніж клінічна форма. Господарства практикують лікувати клінічні прояви маститу. Однак не звертають належної уваги на субклінічні форми маститу, які згодом можуть переходити у хронічну форму запалення. Отримані результати обумовлені санітарними умовами утримання корів, технологією доїння та періодом лактації.

Хоча зв'язок між маститом та патогенними мікроорганізмами був доведений в 1887 році, основні патогени були виявлені лише протягом 1940-х років. Висновок про багатофакторну етіологію маститу великої рогатої худоби відкрив шлях для подальших досліджень маститу, включаючи визначення загальних етіологічних агентів, які були визнані як грампозитивними, так і грам- негативні бактерії, такі як $S$. agalactiae, S. aureus, Escherichia coli (E. coli) та Klebsiella pneumoniae (K. pneumoniae); молекулярна епідеміологія збудників збудників; порівняльні методи типізації збудників на підвиді; масиви генів вірулентності; секвенування цілого геному та дослідження структури сприйнятливості антибіотиків in vitro.

За результатами визначення складу мікрофлори у молоці корів у господарствах Сумської області встановлено, що основними збудниками субклінічного маститу є $S$. agalactiae (20\%), S. aureus (17\%), S. epidermidis (15\%), E. fecalis $(12$ $\%)$, E. coli (10\%), Mycoplasma spp. (8 \%), гриби Candida (7\%) та асоційована мікрофрлора (11\%) (Naqvi et al., 2018).

Як правило, субклінічний мастит у корів під час отелення переважно спричинені головними патогенами, а саме коагулазонегативними стафілококами, що призводять до маститів телиць. На початку лактації на впливають багато факторів, включаючи природу захворювання, вірулентність збудника, час початку відношення до отелення, стійкість інфекції, 
імунітет тварини, термін вагітності та управлінські практики, включаючи ризик, пов'язаний із сезоном та розташування стада. Короткочасне передпологове лікування антибіотиками $€$ ефективним заходом для боротьби з маститом телиць, але воно рідко рекомендується через тривалий несприятливий вплив на здоров'я вимені та виробництво молока, тим самим знижуючи прибуток фрермерів (De Vliegher et al. 2012 ).

Також дослідженнями було доведено, що захворювання корів на субклінічний мастит можна визначати за кількістю соматичних клітин (КСК) у молоці. Пік захворюваності припадає на перший місяць лактації. При цьому в першу лактацію у корів спостерігали збільшення КСК на сьому добу захворювання на 87,4 \%; на десяту - на 143,0\%; на п'ятнадцяту - на 17,0 \%, порівняно до початку хвороби. У корів другої лактації також прослідковується тенденція збільшення запалення вим'я на сьому добу на 78,2 \%; на десяту - на $142 \%$; на п'ятнадцяту - на 8,0 \%. Крім того, можна зазначити, що найбільший рецидив захворювання на субклінічний мастит приходиться з сьомої по десяту добу. На п'ятнадцяту добу захворювання запалення дещо зменшується, на що вказує рівень соматичних клітин в молоці корів. Так у корів 1-5 лактації отримували подібний патогенез захворювання, не залежно від лактації. Однак захворювання поступово зменшуються під кінець періоду лактації і знову виникає рецидив в період запуску. Однак у здорових корів кількість соматичних клітин в молоці може коливатись протягом всього періоду лактації в межах фізіологічної норми. У хворих тварин КСК різко збільшується і може переходити мастит з субклінічної форми у клінічну через не надання своєчасного лікування.

Мастит може бути епідеміологічно класифікований на заразний та екологічний мастит і викликаний широким спектром патогенів. Крім цього, мастит також можна класифікувати як клінічну, так і субклінічну форму (Abebe et al. 2016). Будьяке підвищення рівня вологості та забруднення навколишнього середовища сараю також збільшує навантаження бактеріальних збудників у навколишнє середовище. Одне з досліджень показало поширеність маститу на рівні стада $74,7 \%$, а на рівні корів - 62,6\%. Що стосується субклінічного та клінічного маститу, перший тип, як видається, відповідальний за більшість випадків $(59,2 \%)$, ніж другий $(3,4 \%)$ (Abebe et al. 2016). Клінічний мастит можна легко ідентифікувати на основі видимих симптомів з точки зору запалення вимені, що показує почервоніння в ураженій частині або цілому вимені, тепло, набряк, біль при дотику, згустки молока, зміна кольору та зміна консистенції молока. Загальними симптомами є пірексія $\left(>39,5^{\circ} \mathrm{C}\right)$ та втрата апетиту.

Порівняно з клінічною формою, ніяких клінічно видимих симптомів при субклінічному маститі не спостерігається, хоча зміна складу молока може бути показником. Отже, це визнається та підтверджується лабораторним дослідженням молока або тестами на стороні тварин, такими як каліфорнійський тест на мастит (СМТ) з подальшим лабораторним виділенням збудника.

Кількість соматичних клітин (КСК) у молоці повинна бути менше 200000 на мл у здорової корови. Соматичні клітини - це переважно білі кров'яні клітини (WBC), тобто інфільтровані нейтрофріли, а також макрофаги в тканину молочної залози через запалення (Steeneveld et al. 2011). S. agalactiae в основному локалізується у вимені та викликає стійкі інфекції з вищим SCC.

Діагностика маститу є основною вимогою молочної галузі до чистого виробництва молока не тільки з економічних причин та з точки зору громадського здоров'я, але й щодо добробуту тварин. Діагностика повинна бути ранньою, швидкою та точною для запобігання маститу або раннього виявлення маститу для лікування або терапевтичних цілей. Це передбачає застосування звичайних, а також вдосконалених діагностичних тестів. Звичайні методи відносно дешеві, легкі, швидкодоступні та застосовуються на місцях, але зазвичай неспецифічні. Розширені тести є дорогими, вимагають технічних навичок та складної інфраструктури та обладнання, але, як правило, точні та специфічні для різних форм маститу (Hussein et al., 2018; Chakraborty et al., 2019) .

Вибракування та чітко визначені протоколи біозахисту $€$ есрективними заходами для контролю та запобігання повторному зараженню тварин вірулентними штамами $S$. agalactiae та $S$. aureus). Крім того, поєднання лікування антибіотиками та вибракування корів, що не реагували на протимікробні засоби, продемонструвало зниження швидкості передачі та зменшення проявів субклінічного маститу (Halasa 2012). Для лікування маститу доступні кілька режимів звичайних та вдосконалених терапевтичних заходів, які включають антибіотики, вакцинацію, терапію на основі наночастинок, трав'яну терапію та бактеріоцини (Gomes and Henriques 2016). Різні агенти сприяють зменшенню інфекцій вимені, особливо маститу у корів, а також сприяють поліпшенню якості молока (Skowron et al. 2019). Серед них антибіотикотерапія та вакцинація $€$ загальновживаними методами лікування маститу. Широке та неконтрольоване використання антибіотиків для лікування поряд із індукцією та збереженням стійкості до антибіотиків при маститі призвело до зменшення реакції на антибіотикотерапію (Park et al. 2012; Babra et al. 2013). Хоча вакцинація неефективна проти маститу великої рогатої худоби, оскільки до ії розвитку беруть участь різноманітні мікроорганізми; тим не менш, S. aureus, Streptococcus uberis (S. uberis) та E. coli вважалися основними збудниками для створення вакцин (Bradley et al. 2015; Collado et al. 2016; Ashraf and Imran 2020). Незважаючи на те, що доступні декілька комерційних вакцин, більшість з них не продемонстрували достатнього захисту і водночас є дорогими (Côté-Gravel and Malouin 2019).

Через ці недоліки антибіотиків та вакцин з'явилося кілька інших способів терапії, які можуть заповнити пробіли. Технологія використання пробіотичних штамів мікроорганізмів, які є перспективними для профілактики та лікування субклінічних форм маститу.

Перспектива подальшого дослідження: провести випробування пробіотичних штамів мікроорганізмів для лікування субклінічних форм маститу у корів.

\section{Висновки:}

1. При проведенні маститу різної форми у корів в господарствах Сумської області встановлено, що субклінічна форма маститу діагностувалась частіше ніж клінічна у Сумському районі на 33,4 \%; у Лебединському - на 17,8 \%; у Конотопському - на 45,4 \%; у Шосткінському - на 42,8 \%; у Роменському - на 34,3 \%; у Охтирському - на 21,9 \%.

2. Встановлено, що пік розвитку субклінічного маститу приходиться на 7-10 добу запалення і повертається до початкових значень за два тижні.

3. За результатами визначення основного складу мікрофлори у молоці корів встановлено, що основними збудниками субклінічного маститу $€ S$. agalactiae $(20 \%), S$ aureus $(17 \%)$, S. epidermidis (15\%), E. fecalis $(12 \%)$, E. coli $(10 \%)$, Mycoplasma spp. (8\%), гриби Candida (7\%) та асоційована мікрофрлора (11\%). 


\section{References:}

1. Bardhan D. (2013). Estimates of economic losses due to clinical mastitis in organized dairy farms. Indian J Dairy Sci. 66:168-172. https://doi.org/10.21887/ijvsbt.v13i01.8732

2. Sinha, M. K., Thombare, N. N., \& Mondal, B. (2014). Subclinical mastitis in dairy animals: incidence, economics, and predisposing factors. TheScientificWorldJournal, 2014, 523984. https://doi.org/10.1155/2014/523984

3. Das, D, Panda, S.K., Jena, B., Sahoo, A.K. (2018). Economic impact of subclinical and clinical mastitis in Odisha, India. IntJCurrMicrobiolAppSci. 7(03):3651-3654. https://www.ijcmas.com/7-3-2018/D.\%20Das2,\%20et\%20al.pdf

4. Halasa, T., Huijps, K., Østerås, O., \& Hogeveen, H. (2007). Economic effects of bovine mastitis and mastitis management: a review. The veterinary quarterly, 29(1), 18-31. https://doi.org/10.1080/01652176.2007.9695224

5. Kalińska, A., Jaworski, S., Wierzbicki, M., \& Gołębiewski, M. (2019). Silver and Copper Nanoparticles-An Alternative in Future Mastitis Treatment and Prevention?. International journal of molecular sciences, 20(7), 1672. https://doi.org/10.3390/ijms20071672

6. Klaas, I. C., \& Zadoks, R. N. (2018). An update on environmental mastitis: Challenging perceptions. Transboundary and emerging diseases, 65 Suppl 1, 166-185. https://doi.org/10.1111/tbed.12704

7. Ruegg P. L. (2017). A 100-Year Review: Mastitis detection, management, and prevention. Journal of dairy science, 100(12), 10381-10397. https://doi.org/10.3168/jds.2017-13023

8. Aghamohammadi, M., Haine, D., Kelton, D. F., Barkema, H. W., Hogeveen, H., Keefe, G. P., \& Dufour, S. (2018). HerdLevel Mastitis-Associated Costs on Canadian Dairy Farms. Frontiers in veterinary science, 5, 100. https://doi.org/10.3389/fvets.2018.00100

9. Hamann, J. (2001). Mastitis notes from members countries. Germany Bullt IDF367: 18-21.IDF (1987) Bovine mastitis. Definition and guidelines for diagnosis. Bull IDF. 211:24. https://scholar.google.com/scholar?q=related:eDfXv8M_2tsJ:scholar.google.com/\&scioq=\&hl=uk\&as_sdt=0,5

10. Bennett, R., Christiansen, K., \& Clifton-Hadley, R. (1999). Preliminary estimates of the direct costs associated with endemic diseases of livestock in Great Britain. Preventive veterinary medicine, 39(3), 155-171. https://doi.org/10.1016/s0167-5877(99)000033

11. Hogeveen, H., Pyorala, S., Waller, K. P., Hogan, J. S., Lam, T. J., Oliver, S. P., ... \& Hillerton, J. E. (2011). Current status and future challenges in mastitis research. In Proceedings of the 50th Annual Meeting of the National Mastitis Council, 23-26 January, 2011, Arlington, USA (pp. 36-48).

12. Hadrich, J. C., Wolf, C. A., Lombard, J., \& Dolak, T. M. (2018). Estimating milk yield and value losses from increased somatic cell count on US dairy farms. Journal of dairy science, 101(4), 3588-3596. https://doi.org/10.3168/jds.2017-13840

13. Oliver, S. P., \& Murinda, S. E. (2012). Antimicrobial resistance of mastitis pathogens. The Veterinary clinics of North America. Food animal practice, 28(2), 165-185. https://doi.org/10.1016/i.cvfa.2012.03.005

14. Ruegg P. L. (2009). Management of mastitis on organic and conventional dairy farms. Journal of animal science, $87(13$ Suppl), 43-55. https://doi.org/10.2527/jas.2008-1217

15. Sharun, K., Dhama, K., Tiwari, R., Gugjoo, M. B., Iqbal Yatoo, M., Patel, S. K., Pathak, M., Karthik, K., Khurana, S. K., Singh, R., Puvvala, B., Amarpal, Singh, R., Singh, K. P., \& Chaicumpa, W. (2021). Advances in therapeutic and managemental approaches of bovine mastitis: a comprehensive review. The veterinary quarterly, 41(1), 107-136. https://doi.org/10.1080/01652176.2021.1882713

16. Bhulto, A.L., Murry, R.D., Woldehiwet, Z (2012): California Mastitis Test scores as indicators of subclinical intramammary infections at the end of lactation in dairy cows. Res Vet Sci, 92, 13-17.

17. Prescott, S.C., Breed, R.S. (2010): The determination of the number of body cells in milk by a direct method. American J Pub Hyg, 20, 662-640.

18. Naqvi, S. A., De Buck, J., Dufour, S., \& Barkema, H. W. (2018). Udder health in Canadian dairy heifers during early lactation. Journal of dairy science, 101(4), 3233-3247. https://doi.org/10.3168/jds.2017-13579

19. De Vliegher, S., Fox, L. K., Piepers, S., McDougall, S., \& Barkema, H. W. (2012). Invited review: Mastitis in dairy heifers: nature of the disease, potential impact, prevention, and control. Journal of dairy science, 95(3), 1025-1040. https://doi.org/10.3168/ids.2010-4074

20. Abebe, R., Hatiya, H., Abera, M., Megersa, B., \& Asmare, K. (2016). Bovine mastitis: prevalence, risk factors and isolation of Staphylococcus aureus in dairy herds at Hawassa milk shed, South Ethiopia. BMC veterinary research, 12(1), 270. https://doi.org/10.1186/s12917-016-0905-3

21. Steeneveld, W., van Werven, T., Barkema, H. W., \& Hogeveen, H. (2011). Cow-specific treatment of clinical mastitis: an economic approach. Journal of dairy science, 94(1), 174-188. https://doi.org/10.3168/jds.2010-3367

22. Andrews, T., Neher, D. A., Weicht, T. R., \& Barlow, J. W. (2019). Mammary microbiome of lactating organic dairy cows varies by time, tissue site, and infection status. PloS one, 14(11), e0225001. https://doi.org/10.1371/journal.pone.0225001

23. Hussein, H. A., El-Razik, K., Gomaa, A. M., Elbayoumy, M. K., Abdelrahman, K. A., \& Hosein, H. I. (2018). Milk amyloid A as a biomarker for diagnosis of subclinical mastitis in cattle. Veterinary world, 11(1), 34-41. https://doi.org/10.14202/vetworld.2018.34$\underline{41}$

24. Chakraborty, S., Dhama, K., Tiwari, R., Iqbal Yatoo, M., Khurana, S. K., Khandia, R., Munjal, A., Munuswamy, P., Kumar, M. A., Singh, M., Singh, R., Gupta, V. K., \& Chaicumpa, W. (2019). Technological interventions and advances in the diagnosis of intramammary infections in animals with emphasis on bovine population-a review. The veterinary quarterly, 39(1), 76-94. https://doi.org/10.1080/01652176.2019.1642546

25. Halasa T. (2012). Bioeconomic modeling of intervention against clinical mastitis caused by contagious pathogens. Journal 
of dairy science, 95(10), 5740-5749. https://doi.org/10.3168/ids.2012-5470

26. Gomes, F., \& Henriques, M. (2016). Control of Bovine Mastitis: Old and Recent Therapeutic Approaches. Current microbiology, 72(4), 377-382. https://doi.org/10.1007/s00284-015-0958-8

27. Skowron, K., Sękowska, A., Kaczmarek, A., Grudlewska, K., Budzyńska, A., Białucha, A., \& Gospodarek-Komkowska, E. (2019). Comparison of the effectiveness of dipping agents on bacteria causing mastitis in cattle. Annals of agricultural and environmental medicine : AAEM, 26(1), 39-45. https://doi.org/10.26444/aaem/82626

28. Park, Y. K., Fox, L. K., Hancock, D. D., McMahan, W., \& Park, Y. H. (2012). Prevalence and antibiotic resistance of mastitis pathogens isolated from dairy herds transitioning to organic management. Journal of veterinary science, 13(1), 103-105. https://doi.org/10.4142/jvs.2012.13.1.103

29. Babra, C., Tiwari, J. G., Pier, G., Thein, T. H., Sunagar, R., Sundareshan, S., Isloor, S., Hegde, N. R., de Wet, S., Deighton, M., Gibson, J., Costantino, P., Wetherall, J., \& Mukkur, T. (2013). The persistence of biofilm-associated antibiotic resistance of Staphylococcus aureus isolated from clinical bovine mastitis cases in Australia. Folia microbiologica, 58(6), 469-474. https://doi.org/10.1007/s12223-013-0232-z

30. Bradley, A. J., Breen, J. E., Payne, B., White, V., \& Green, M. J. (2015). An investigation of the efficacy of a polyvalent mastitis vaccine using different vaccination regimens under field conditions in the United Kingdom. Journal of dairy science, 98(3), 1706-1720. https://doi.org/10.3168/jds.2014-8332

31. Collado, R., Prenafeta, A., González-González, L., Pérez-Pons, J. A., \& Sitjà, M. (2016). Probing vaccine antigens against bovine mastitis caused by Streptococcus uberis. Vaccine, 34(33), 3848-3854. https://doi.org/10.1016/j.vaccine.2016.05.044

32. Ashraf, A., \& Imran, M. (2020). Causes, types, etiological agents, prevalence, diagnosis, treatment, prevention, effects on human health and future aspects of bovine mastitis. Animal health research reviews, 21(1), 36-49. https://doi.org/10.1017/S1466252319000094

33. Côté-Gravel, J., \& Malouin, F. (2019). Symposium review: Features of Staphylococcus aureus mastitis pathogenesis that guide vaccine development strategies. Journal of dairy science, 102(5), 4727-4740. https://doi.org/10.3168/jds.2018-15272

Yaroslav Tytukh, PhD Student, Sumy National Agrarian University (Sumy, Ukraine)

Performance monitoring includes various forms of mastitis in Sumy region farms

The article presents the results of monitoring of cows mastitis in Sumy region. Mastitis (Mastitis is inflammation of the udder,) caused by infectious agents is still considered destructive to dairy animals, affecting animal welfare and causing huge economic losses to the dairy industry due to reduced productivity and increased culling.

The study was conducted on dairy farms in Sumy region. The procedures of human behavior with animals were approved by the Ethics Committee of Sumy National Agrarian University (approval №: 2021/01). Animals are kept in ox stalls with three times a daily milking. The experiments were performed on Holstein cattle during 1-5 lactations.

It was found that subclinical forms of mastitis are registered much more often than clinical ones. Subclinical mastitis was monitored by the somatic cell count (SCC) in milk. In the first months after calving cows are most often affected by subclinical mastitis due to physiological stress. The disease gradually decreases at the end of lactation and recurrence occurs again during completed lactation. However, the somatic cell count in milk of healthy cows can fluctuate throughout the lactation period within the physiological norm. The somatic cell count in sick animals sharply increases and mastitis can change from a subclinical form to clinical.

Performance monitoring includes various forms of mastitis in Sumy region farms, demonstrated that the subclinical form of mastitis was diagnosed more often than the clinical one: in Sumy district by 33,4\%; in Lebedyn district by 17,8\%; in Konotop district by 45,4\%; in Shostka district by 42.8\%; in Romny district by 34,3\%; in Okhtyrka district by 21,9\%. It was found that the peak of subclinical mastitis occurs on day 7-10 of inflammation and returns to baseline in two weeks. The main pathogens of subclinical mastitis were: $S$. agalactiae (20\%), S. aureus (17\%), S. epidermidis (15\%), E. fecalis (12\%), E. coli (10\%), Mycoplasma spp. (8\%), Candida fungi (7\%) and associated microflora (11\%), according to the results of the milk microflora composition.

Key words: cows, subclinical mastitis, clinical mastitis, pathogens of subclinical mastitis, lactation 